\title{
Comparative evaluation of different barrier configurations for electricity substation noise reduction by acoustic simulation
}

\author{
A valiação comparativa de diferentes configurações de barreira para redução de ruídlo de \\ subestação elétrica por simulação acústica \\ Comparativa de diferentes configuraciones de barrera para la reducción de ruido de subestaciones \\ eléctricas mediante simulación acústica
}

Received: 04/22/2021 | Reviewed: 05/04/2021 | Accept: 05/07/2021 | Published: 05/21/2021

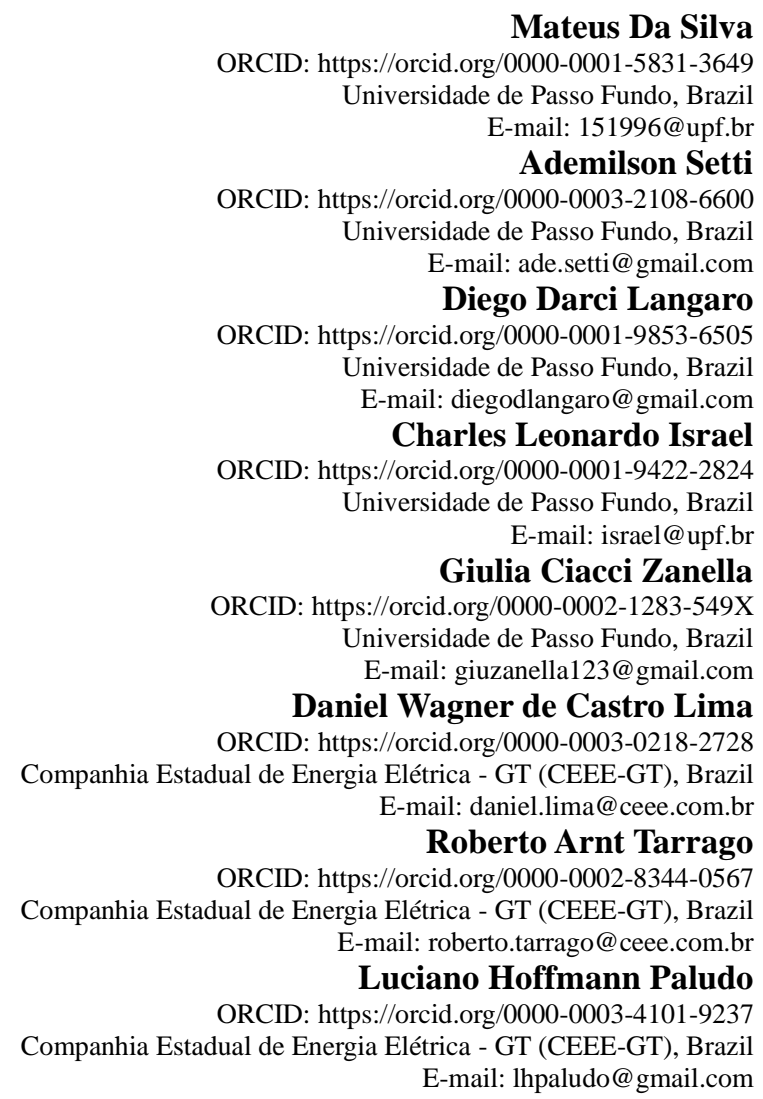

\begin{abstract}
From an analytical study related to an electric power substation, a computational model for acoustic simulation was developed, which made it possible to verify the sound pressure behavior in the regions adjacent to it. With the objective of mapping changes in the level of sound pressure, thus enabling checks related to the operation of acoustic barriers. The model was calibrated based on data from experimental measurements linked to the transformers present in the substation and the values measured around the substation. With that, four different types of acoustic barriers were tested, in which their respective top geometries were changed. From then on, variations in vertical and horizontal sound dispersion were examined, in addition to the noise level in the homes and buildings neighboring the substation. According to the simulation of the different variations and barrier configurations, reduction values from $3 \mathrm{~dB}$ to $17 \mathrm{~dB}$ were found. Finally, the possible difficulties for the practical implementation of each barrier configuration were indicated.
\end{abstract}

Keywords: Substation; Noise mitigation; Sound analysis; Acoustic map; Acoustic barriers.

\section{Resumo}

A partir de um estudo analítico, relacionado à uma subestação de energia elétrica, desenvolveu-se um modelo computacional para simulação acústica, o qual possibilitou verificar o comportamento da pressão sonora nas regiões adjacentes à mesma. Tendo como objetivo mapear as alterações do nível de pressão sonora, assim possibilitando 
verificações relacionadas ao funcionamento de barreiras acústicas. Calibrou-se o modelo a partir de dados oriundos de medições experimentais vinculadas aos transformadores presentes na subestação e à valores mensurados no entorno da mesma. Com isso, testou-se quatro diferentes tipos de barreiras acústicas, nas quais foram alteradas as suas respectivas geometrias de topo. A partir de então, examinou-se as variações na dispersão sonora vertical e horizontal, além do nível sonoro incidente nas residências e construções vizinhas a subestação. De acordo com a simulação das diferentes variações e configurações de barreira, foram encontrados valores de redução de $3 \mathrm{~dB}$ até $17 \mathrm{~dB}$. Por fim, indicou-se as possíveis dificuldades para a implementação prática de cada uma das configurações de barreira.

Palavras-chave: Subestação; Mitigação de ruído; Análise Sonora; Mapa acústico; Barreiras acústicas.

\section{Resumen}

A partir de un estudio analítico, relacionado con una subestación de energía eléctrica, se desarrolló un modelo computacional de simulación acústica que permitió verificar el comportamiento de la presión sonora en las regiones adyacentes a la misma. Con el objetivo de cartografiar los cambios en el nivel de presión sonora, posibilitando así controles relacionados con el funcionamiento de las barreras acústicas. El modelo fue calibrado en base a datos de mediciones experimentales vinculadas a los transformadores presentes en la subestación y los valores medidos alrededor de la subestación. Con esto, se probaron cuatro tipos diferentes de barreras acústicas, en las que se cambiaron sus respectivas geometrías superiores. A partir de entonces, se examinaron las variaciones en la dispersión del sonido vertical y horizontal, además del nivel de ruido en las viviendas y edificios aledaños a la subestación. De acuerdo con la simulación de las diferentes variaciones y configuraciones de barrera, se encontraron valores de reducción de $3 \mathrm{~dB}$ a 17 dB. Finalmente, se indicaron las posibles dificultades para la implementación práctica de cada configuración de barrera.

Palabras clave: Subestación; Mitigación de ruido; Análisis de sonido; Mapa acústico; Barreras acústicas.

\section{Introduction}

The World Health Organization (WHO), in 2011, classified noise pollution as the second largest polluting source, only behind air pollution. Due to its severity, not only hearing loss is taken into account, but also factors such as irritability, concentration difficulties, increased blood pressure, accelerated pulse, psychological effects, behavioral and sleep changes (WHO, 2011).

In a study by de Castro et al. (2019), in two different schools, regarding the impact of noise pollution in relation to the levels of learning and concentration, it was possible to observe that the noise negatively affected the students' performance, having been aggravated in the case of rooms with a higher noise level, which indicates the need to reduce it. In another study by Assunção et al. (2019), in relation to cognitive performance, it indicated problems related to memory and the sleep cycle of people exposed to intense noise.

To reduce noise and mitigate the aforementioned problems, actions can be taken at one or more of the following points: at the emitting source, propagation medium or the receiver (Bies \& Hansen, 2003). This study seeks ways to mitigate noise in its propagation medium, by using acoustic barriers, adding to them configurations and characteristics that can reduce the sound level of a certain region, causing little or no adverse effect to the people who are there.

The main noise sources of the simulated substation are the power transformers. The substation has six transformers in three different voltage levels.

Different geometries for barriers and top geometries were studied in order to improve their characteristics regarding acoustic absorption and reflection, thus seeking a configuration that contemplates noise reduction without causing unwanted impacts. The simulation was built to resemble reality as much as possible, and from the initial model different barriers were created and the effectiveness of each one was verified.

Sound can be characterized as the variation of pressure caused by the vibration of a material, and promotes an increase in the agitation of molecules, thus reaching the ear. The human ear is able to distinguish sounds present in only one frequency range, which starts at $20 \mathrm{~Hz}$, representing the lowest sounds, and ends at $20000 \mathrm{~Hz}$, characterizing high-pitched sounds. The frequencies below $20 \mathrm{~Hz}$ are called infrasounds and those above $20000 \mathrm{~Hz}$ are called ultrasounds (Bies \& Hansen, 2003). 
When the sound you hear is unpleasant, annoying and/or may generate damage to human health is classified as noise (ABNT NBR 10151, 2020). Besides not hearing all the sound frequencies the human ear has different perceptions for each frequency variation, thus generating different isophonic lines. The isophonic lines translate into equal sensitivities for different points of the same curve (Bies \& Hansen, 2003).

The way sound is propagated outdoors is directly influenced by weather conditions, i.e. air humidity, wind, temperature, soil sound absorption coefficient and vegetation. Each condition influences in a way the way the sound behaves and thus changes the way it is transported (Wakefield Acoustics, 2012).

The sound absorption generated by the atmosphere and humidity varies according to the sound frequency, being higher for higher frequencies. This occurs due to the shorter wavelength, which is lost more easily during induction transfer between molecules (Larsson, 1997).

When the sound source or the receiver are close to the ground the sound wave can be influenced by it, because part of it will be affected by reflections and may cause interference in the direct wave, thus generating the so-called ground effect, which is the combination of both waves, the direct and the reflected (Leissing, 2007).

Other characteristics that can influence the wave are the frequency and rigidity of the ground. If the surface is porous, it will have absorving characteristics, thus reducing the sound power, occurring the opposite if the soil is reflective. The frequencies that are most influenced by the soil are between 200 and $600 \mathrm{~Hz}$ (Attenborough, 2002).

The sound wave, when intercepted by some kind of obstacle, modifies a series of different factors, such as reflection, absorption, diffraction and transmission. Some of them can be eliminated or attenuated, depending on the type of material and characteristics that will describe the obstacle. Examples of how such factors happen can be seen in Figure 1 (Daigle, 1999).

Figure 1 - Sound wave propagation by obstacle.

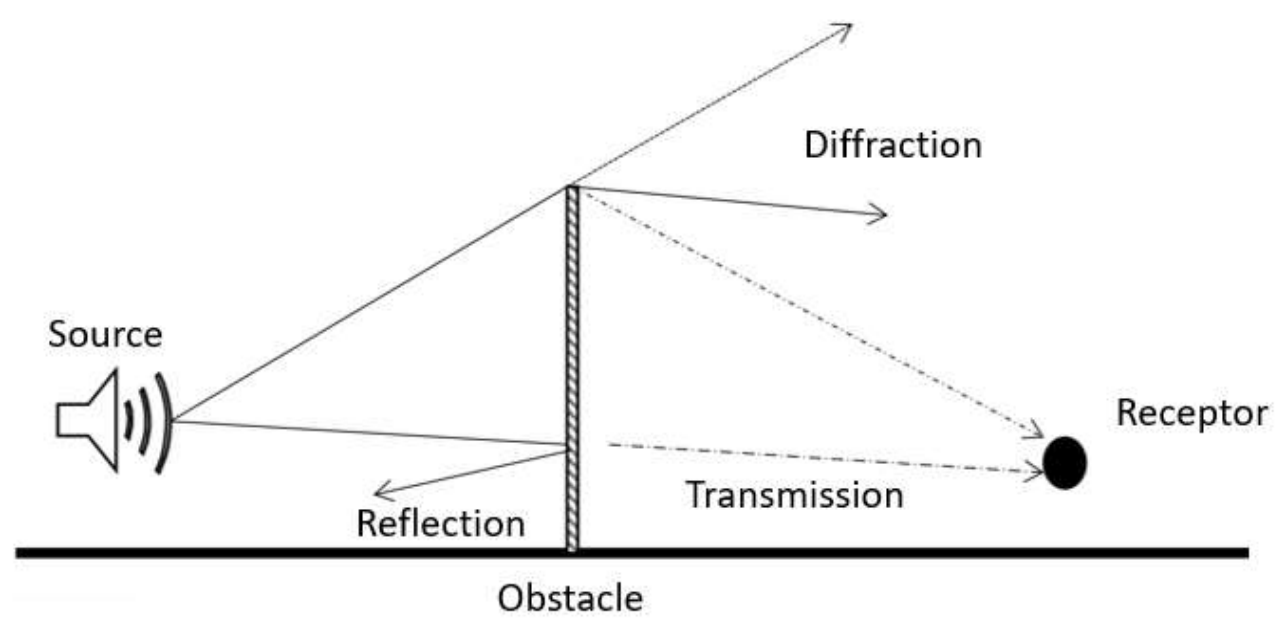

Source: FHWA (2014).

The wave that falls on the top of the barrier suffers diffraction, varying according to the angle of incidence and the shape of this top, as well as the wavelength (FHWA, 2014). The receiver is affected only by the transmitted and diffracted waves since the reflected waves return towards the source and the absorbed waves are dissipated in the form of heat by the barrier material (Freitas \& Trabulo, 2007).

High frequency sound waves are hardly diffracted because they have a small wavelength, unlike low frequency waves, which are diffracted at a greater angle towards the receiver due to their large wavelength, making the barriers less efficient for low frequencies (FHWA, 2014)(Hendriks et al., 2013). 


\section{Methodology}

To achieve the stated objectives the best indicator that can be used to check the influence or effectiveness of a barrier is called Insertion Loss (IL). In summary, IL represents how much the sound level was affected before and after the insertion of the barrier, indicating if the barrier is capable of attenuating the sound (Radoi, 2015).

The performance of a barrier is in part linked to factors related to its construction. In this section some of these factors will be addressed, which were considered more important for the present work (Freitas \& Trabulo, 2007).

The geometry of the barrier interferes with how the sound is reflected by it, but this also depends on the angle at which the wave is reflected (Tadeu et al., 2012).

Another geometric factor that influences the IL is the geometry in barrier top, which aims to alter the diffraction angle and decrease the sound level, increasing considerably the insertion loss (Daigle, 1999). During a study the variation of the IL was compared, having as reference a barrier of 2 meters of height, showing the influence of a top geometry in a "T" shape with lateral flaps, as shown in Figure 2 (Watts, 2002).

Figure 2 - Top configurations.

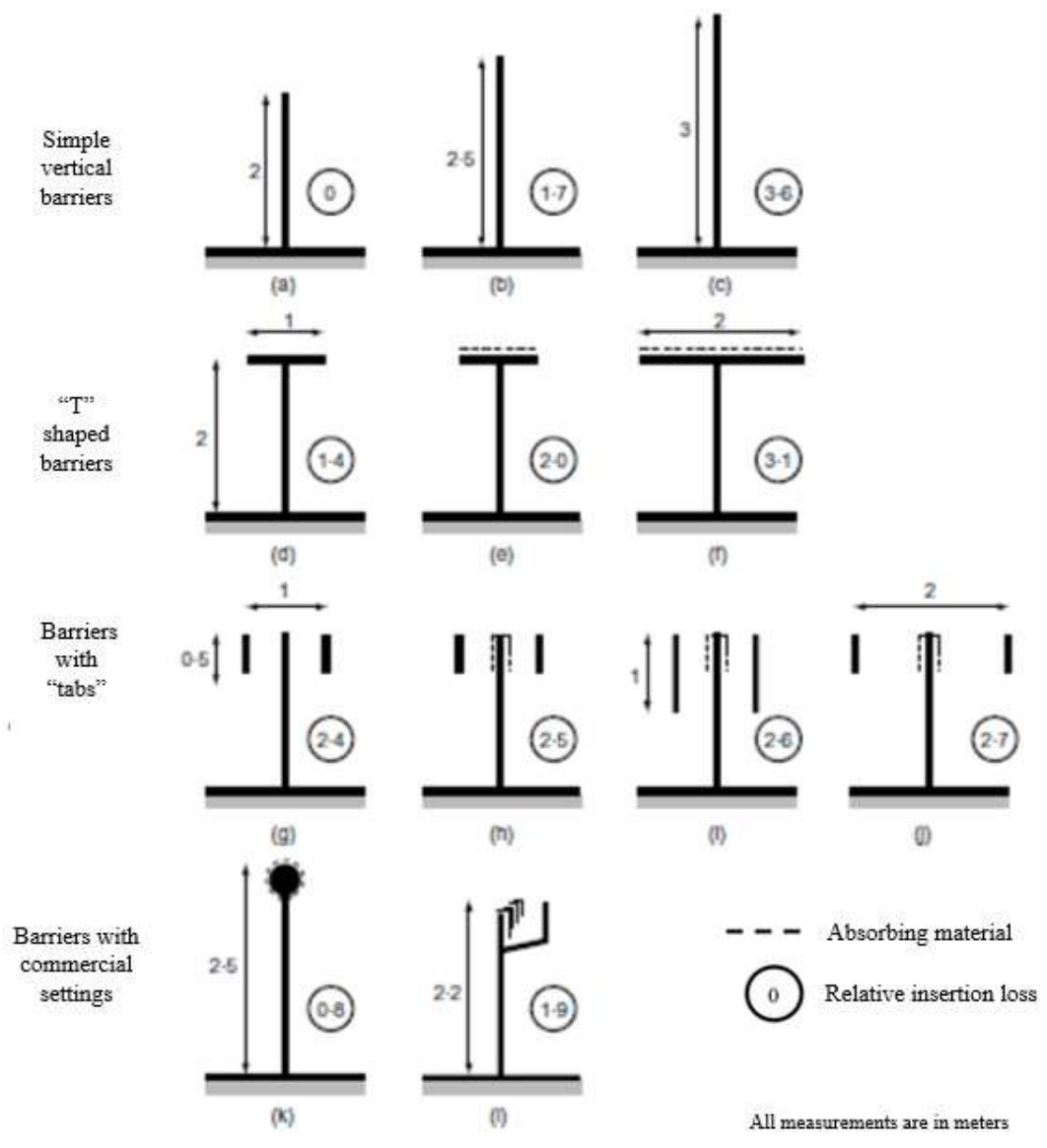

Source: Watts (2002).

The insertion loss also varies according to the distance between barrier and sound source, or barrier/receiver, so that the closer to the source or receiver it is, the greater the IL (Hendriks et al., 2013).

Fachin (2005) indicates that the comparative method covers facts and data in order to show similarities and divergences in elements present in both cases, so a comparative methodology was used, in order to find the IL values generated by each variant, being the variant $\mathrm{C} 1 \mathrm{~A}$, created from the actual situation of the substation. 
In order to increase the reliability of the simulation results and improve its accuracy, the substation was modeled from a map file, imported into CadnaA via GoogleMaps. Also, a substation plan was inserted to the modeling in order to allow a more accurate identification and positioning of the transformers. The terrain around the substation was also inserted, as well as the relief topography where the substation is located.

From the technical drawings of the transformers (TR1, TR2, TR3, TR4, TR5 and TR6), shown in Fig. 3 (a), it was possible to find their dimensions, being the noise spectra obtained from an experimental test and presented in (Langaro \& Setti, 2020).

\section{Development}

In order to glimpse the possible noise reduction, 4 different configurations were simulated, each containing their respective acoustic barriers, comparing them with the current situation in the substation. The synthesis of all configurations created, C2, C3, C4 and C5, plus the current situation, C1A, is presented in Table 1.

The first configuration defined, $\mathrm{C} 2$, is 2 meters longer than the transformer side, i.e. on a 6 meter long side the barrier will be 8 meters long, 1 meter more for each side and 6 meters high. In the second one, C3, it was chosen to completely enclose the sides of the transformers, defining the height as also being 6 meters. Also, it should be noted that these barriers were positioned at a distance of $3 \mathrm{~m}$ from each side of the transformers, thus seeking to avoid possible heating when they are in operation.

For the third configuration tested, $\mathrm{C} 4$, barriers have been defined with a height higher than the previous ones, of 9 meters, which have been positioned where the substation walls are, i.e. on their perimeter. Finally, a configuration was tested using perimeter barriers together with others near the transformers, C5.

All the configurations created were tested by adding top geometries next to the barriers in $\mathrm{T}$ format. The length of the tabs was defined as 1.5 meters. Vertical calculation areas were created to allow the visualization of the variations generated by each of the different arrangements.

The current simulated configuration, C1A, is presented below, as well as the barriers already present (B1, B2 and B3 Figure 6 (b)) for noise reduction. It is possible to observe the bitmap and the substation plan together with the existing constructions in the adjacent region. Figure 6 (a) shows the upper view of the substation, modeled in the CadnaA software, making it possible to view the map file. In Figure 6 (b) a 3D image of the modeled area is shown.

Figure 3 - Views of the substation simulation.

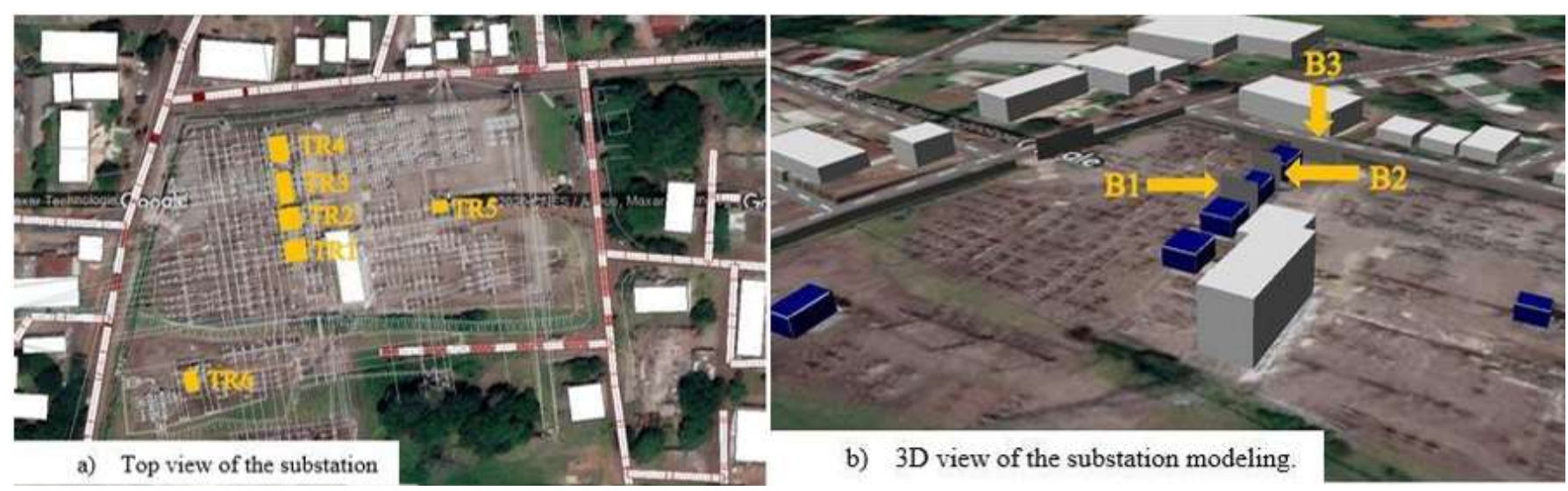

Source: Authors. 
In the top of Figure 10, the positioning of the barriers is indicated, in green those used to enclose the transformers, as defined for $\mathrm{C} 3$, in orange the side barriers, for the $\mathrm{C} 2$ configuration, and in yellow, the positioning of the barrier on the perimeter of the substation, configuration $\mathrm{C} 4$, as shown in Table 1. It should be noted that the locations of the barriers in green and yellow were also defined for the case of $\mathrm{C} 5$.

Figure 4 - Position of the simulated barriers.

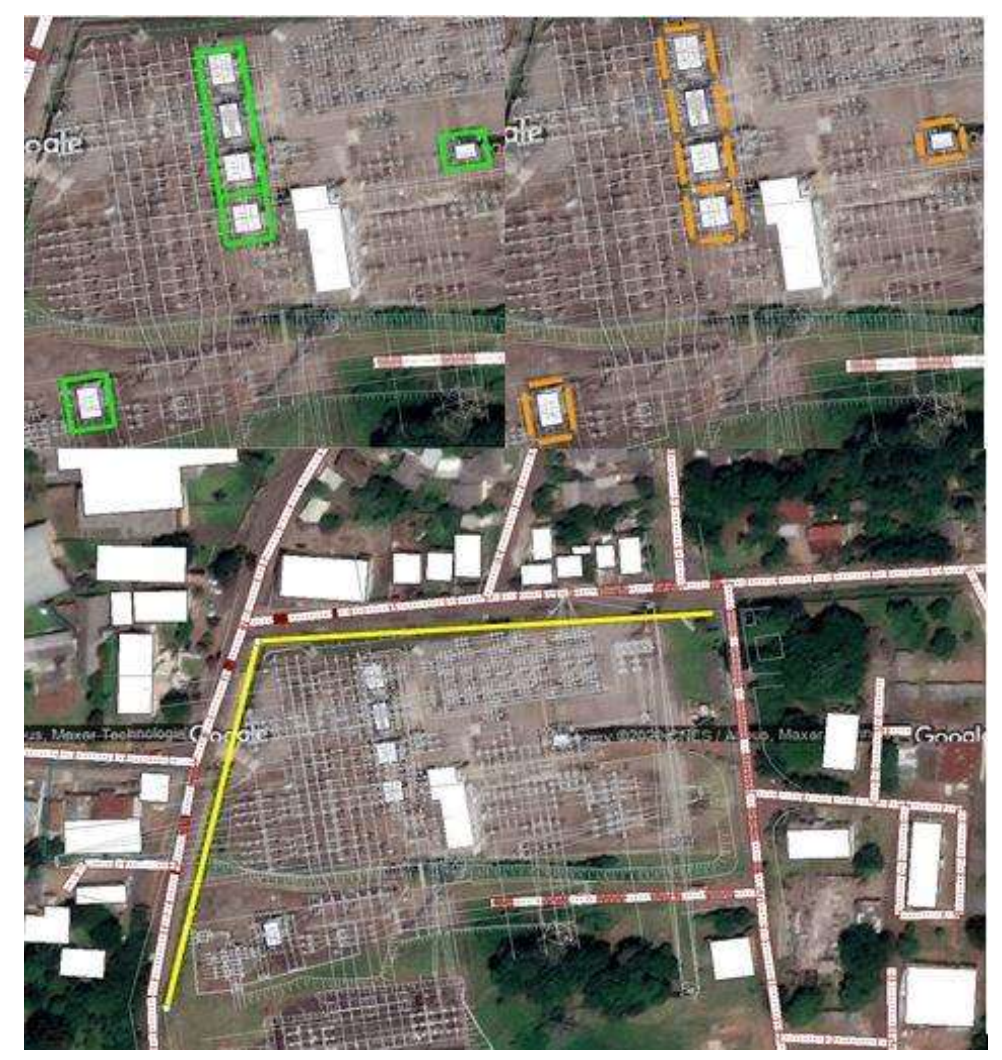

Source: Authors.

Among the TR2, TR3 and TR4 transformers, positioned closer to the upper edges of the images, no new barriers have been inserted, as the substation already contemplates 2 barriers of 8.20 meters in height between them.

Table 1, previously commented, and presented below, synthesizes the analyzed and simulated configurations, facilitating the understanding regarding the strategies created. In this table the indicative TR, refer to transformers, LTR refer to the width of the transformer, CTR refer to the length of the transformer. 
Table 1 - Summary of Defined and Simulated Strategies.

\begin{tabular}{|c|c|c|c|c|c|c|}
\hline \multirow[t]{2}{*}{ Configuration } & \multirow{2}{*}{$\begin{array}{c}\text { Top } \\
\text { Geometry }\end{array}$} & \multicolumn{2}{|c|}{$\begin{array}{c}\text { Enclosure of the } \\
\text { TR }\end{array}$} & \multirow[t]{2}{*}{ Positioning } & \multicolumn{2}{|c|}{ Dimensions } \\
\hline & & Yes & No & & Height & Length \\
\hline $\mathrm{C} 1 \mathrm{~A}$ & & & $X$ & $\begin{array}{l}\text { B1 - between TR2 and TR3 } \\
\text { B2 - between TR3 and TR4 } \\
\text { B3 - between TR4 and Perimeter } \\
\text { (Figure 6) }\end{array}$ & $\begin{array}{c}\mathrm{B} 1-8,2 \mathrm{~m} \\
\mathrm{~B} 2-8,2 \mathrm{~m} \\
\mathrm{~B} 3-4 \mathrm{~m}\end{array}$ & $\begin{array}{l}\text { B1 }-7,5 \mathrm{~m} \\
\mathrm{~B} 2-7,5 \mathrm{~m} \\
\mathrm{~B} 3-18 \mathrm{~m}\end{array}$ \\
\hline $\mathrm{C} 2$ & $X$ & & $X$ & $\begin{array}{l}\text { Next to the TRs } \\
\text { (Figure 7) }\end{array}$ & $6 \mathrm{~m}$ & $\begin{array}{l}\mathrm{CTR}+2 \mathrm{~m} \\
\mathrm{LTR}+2 \mathrm{~m}\end{array}$ \\
\hline $\mathrm{C} 3$ & $\mathrm{X}$ & $\mathrm{X}$ & & $\begin{array}{l}\text { Next to the TRs } \\
\text { (Figure 7) }\end{array}$ & $6 \mathrm{~m}$ & - \\
\hline $\mathrm{C} 4$ & $X$ & & $X$ & $\begin{array}{l}\text { Substation Perimeter } \\
\text { (Figure 8) }\end{array}$ & $9 \mathrm{~m}$ & $310 \mathrm{~m}$ \\
\hline $\mathrm{C} 5$ & $X$ & $X$ & & $\begin{array}{l}\text { Next to the TRs } \\
\text { (Figure 10) } \\
\text { Substation Perimeter } \\
\text { (Figure 8) }\end{array}$ & $9 \mathrm{~m}$ & $310 \mathrm{~m}$ \\
\hline
\end{tabular}

Source: Authors.

\section{Results and Discussion}

The simulation of the substation from the current C1A configuration, has the purpose of observing the noise behavior in the region without implementing the strategies defined for this study. Using such simulation and based on direct and numerical comparisons, it is intended to verify the efficiency of the configurations created, analyzing possible variations in the noise maps. This will make it possible to conclude on benefits obtained from the use of barriers, as well as the influence of their top geometries and other criteria already defined.

In Figure 5 is presented the legend referring to the colors present in the simulation, which inform the intervals between noise levels and ensure a correct interpretation of the noise.

Figure 5 - Color legend present in the simulation.

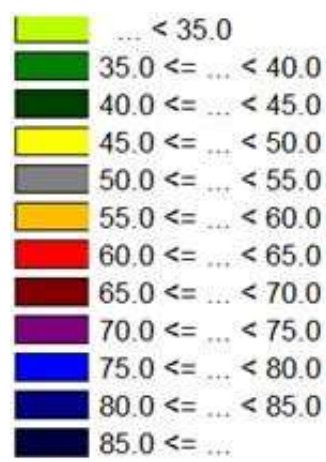

Source: Authors. 
The current noise distribution over the entire substation area as well as the sound level in the nearby houses are indicated in Figure 6 as horizontal noise maps. The noise map shows sound levels ranging from 35 dB, in regions further away from the substation, to more than $85 \mathrm{~dB}$, close to TR4 and TR 1 transformers, which corroborates the experimental study of Langaro and Setti (2020), used to calibrate the simulated model and indicated in this work as C1A.

When examining the maximum noise levels, defined by Municipal Law No 4763 and Resolution N ${ }^{\circ}$. 02/2015, it can be seen that some locations adjacent to the substation are impacted with an incidence of noise above that allowed. Both the experimental study of Langaro and Setti (2020) and the acoustic simulation of the current situation of the substation indicate the veracity of what was exposed. Thus, it is expected that with the proposed configurations, which are presented in sequence, it will be possible to define a viable alternative to mitigate the noise at accepted levels, which meet the regulations in force.

Figure 6 - Top view of the substation with the C1A configuration.

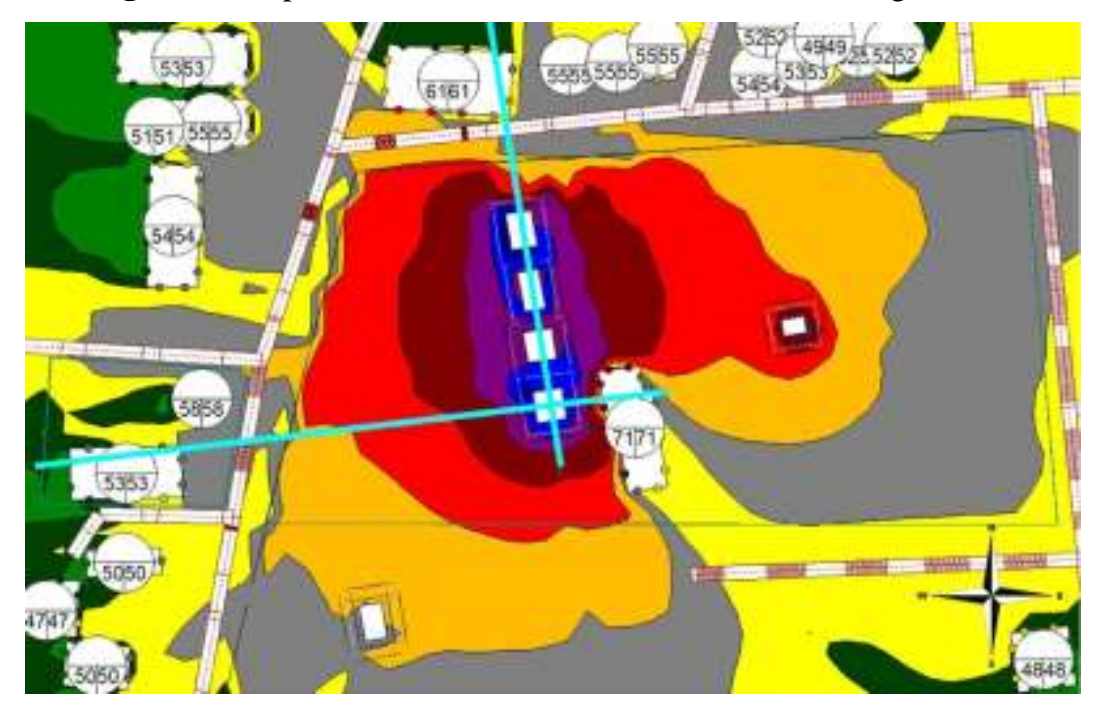

Source: Authors.

Figure 6 shows two blue lines crossing the transformers and the control building, located in the center of the substation, which indicate the position of the vertical calculation areas, which will be presented later. Still in Figure 6 it is possible to verify that the sound waves disperse in a radial way, being slightly contained by the existing barriers and walls that surround the substation.

The following are the variations caused by the barriers arranged on the four sides of the transformers, a configuration called C2. These barriers are 2 meters larger than the dimensions of the transformer sides, thus reducing sound diffraction. The upper view of the simulation is shown next in Figure 7, indicating the sound level at the homes after the barriers are inserted. When comparing the results obtained with the $\mathrm{C} 2$ and $\mathrm{C} 1 \mathrm{~A}$ configurations, a reduction of approximately $3 \%$ is noticed when simulating with $\mathrm{C} 2$.

In Figure 7 the influence of the barriers on the form of sound dispersion is visible, causing a large reduction in the regions after the barriers, which correspond to the colors red and bordered. In the regions where there was no interference the sound was dispersed in a very similar way to the dispersion that occurred in the C1A configuration, thus generating a low level of noise mitigation. 
Figure 7 - Top view of the substation with the $\mathrm{C} 2$ configuration.

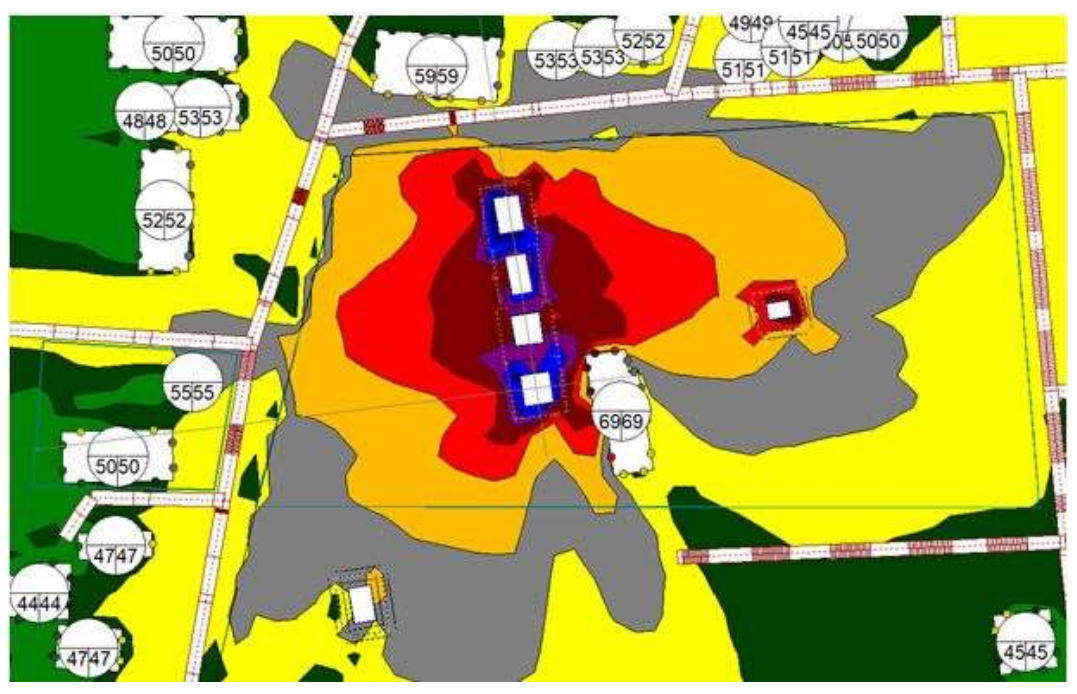

Source: Authors.

The C3 configuration, presented below, contemplates barriers that enclose the transformer sides, having 6 meters and height and being positioned 3 meters from them, in the same way as in $\mathrm{C} 2$. The horizontal noise map generated by the $\mathrm{C} 3$ configuration is shown in Figure 8, together with the noise level at the homes near the substation. When the values of C1A and C3 are compared, a reduction of about $13 \%$ in the sound pressure level can be verified. Due to the encapsulation characteristic of the adopted configuration, the sound wave is dispersed with lower levels than the other configurations, this way it propagates with less energy, in and around the substation. Another explanation for this can be found in Figure 1 located in section 2.3, which indicates that the total enclosure reduces the diffraction of the sound wave since it will not circumvent the barrier or move towards the residence.

Figure 8 - Top view of the substation with the $\mathrm{C} 3$ configuration.

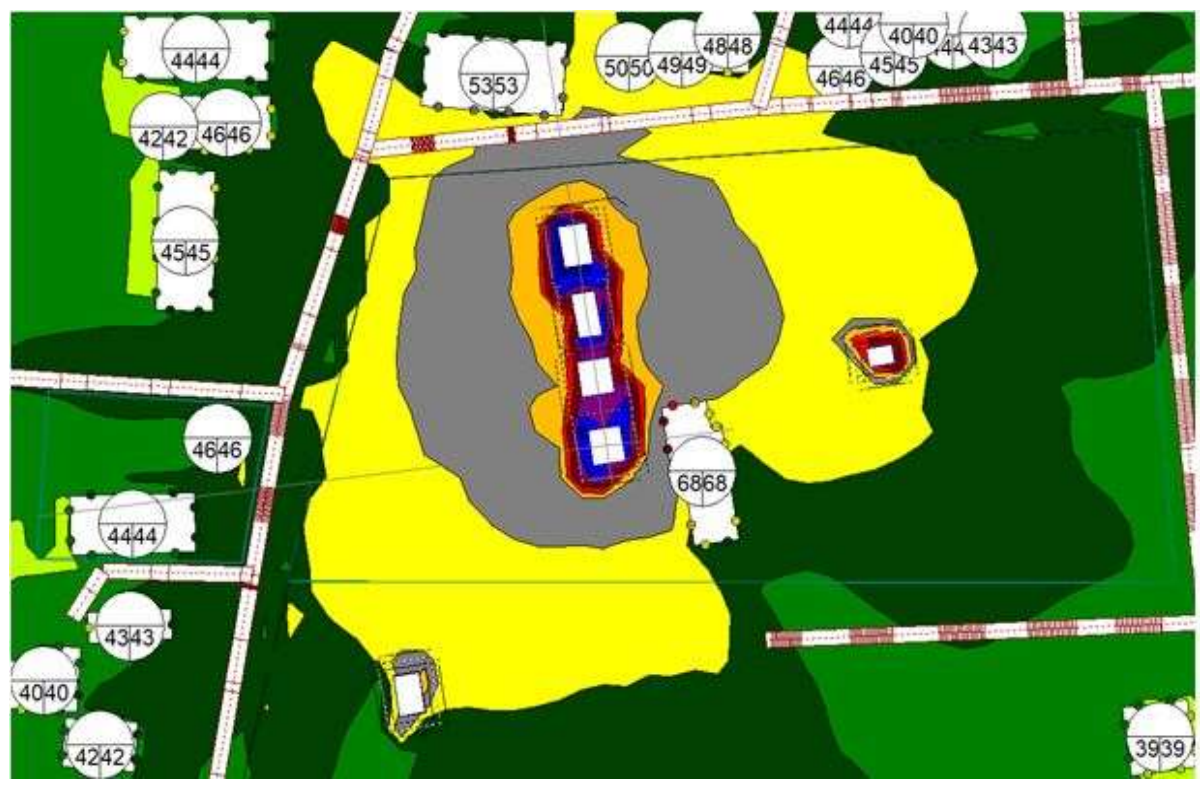

Source: Authors.

The following are the simulations with barriers on the perimeter of the substation, a configuration named $\mathrm{C} 4,9$ meters high. The upper view of the substation with the sound level of the nearby residences and the position of the barriers in blue is 
shown in Figure 9. This shape of barrier has a more expensive construction due to the size and position of the barriers, but has the advantage of the distance from the transformers, not hindering the cooling and care with their wiring. Such a barrier format may have the disadvantage of municipal regulations related to the environment and urban issues.

The values of the noise level incident in homes, from the simulation of the $\mathrm{C} 4$ configuration, are up to $21 \%$ lower than those presented for $\mathrm{C} 1 \mathrm{~A}$, and this reduction is partly generated by the shadow zone of the barriers, which extends over the dwellings adjacent to the substation, thus allowing noise attenuation.

Figure 9 - Top view of the substation with the C4 configuration.

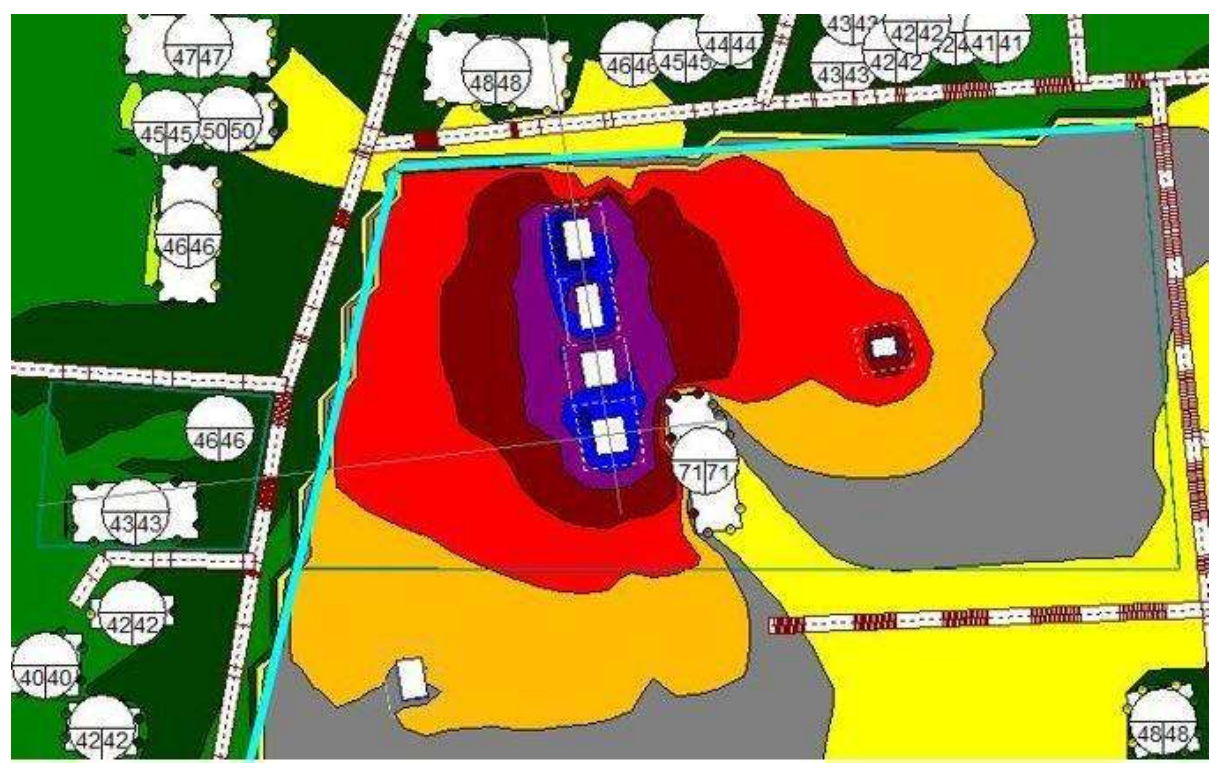

Source: Authors.

Finally, a simulation was carried out combining the variants named $\mathrm{C} 3$ and $\mathrm{C} 4$, this configuration features barriers that enclose the transformer sides, as well as barriers on the substation perimeter. Such configuration is indicated in Table 1 as C5.

Figure 10 shows the upper view of the substation, indicating from the color scheme the distribution and intensity of the noise as well as the level incident in the neighboring homes. By comparing it with the simulation of the current substation situation, C1A, a noise reduction of up to $29 \%$ can be verified. In comparison with the configurations $\mathrm{C} 3$ and $\mathrm{C} 4$, which originate $\mathrm{C} 5$, a reduction of 4 to $6 \mathrm{~dB}$ can be noticed. 
Figure 10 - Top view showing sound values and sound distribution for the C5 configuration.

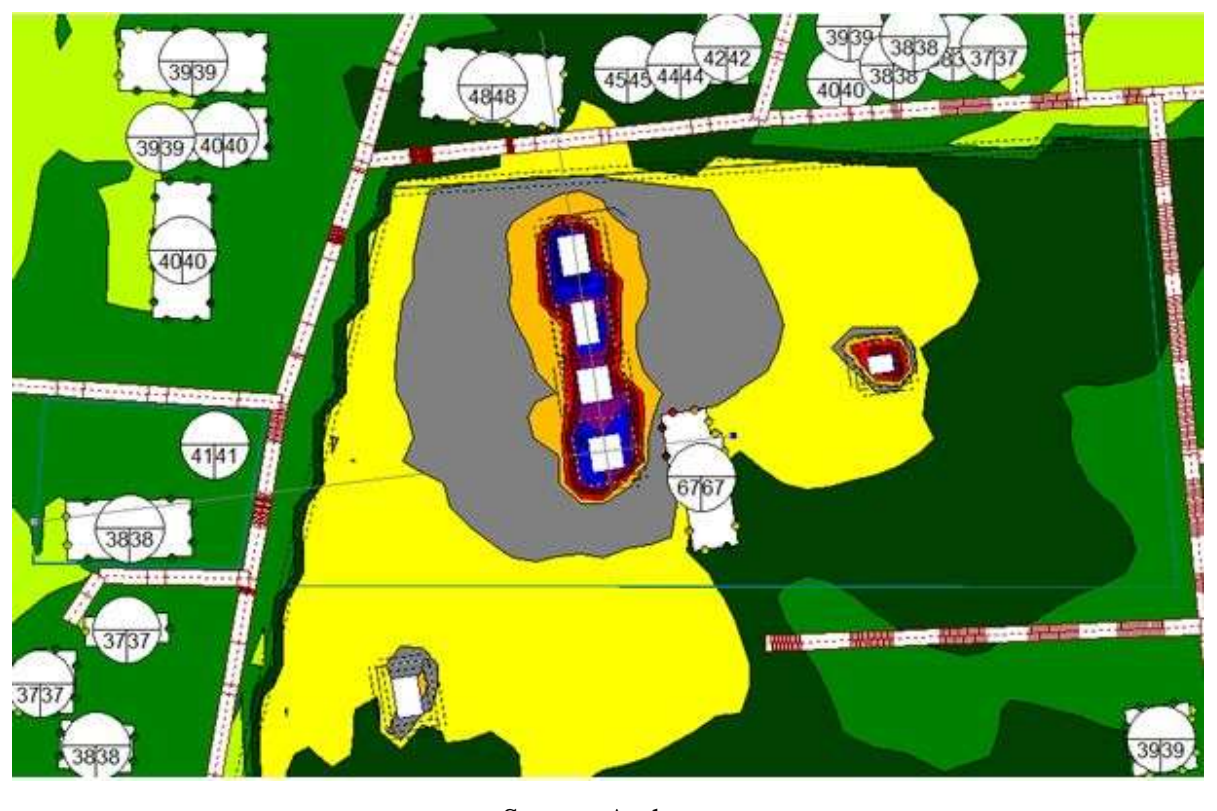

Source: Authors.

In order to improve understanding of the C5 configuration, a 3D view of it is shown in Figure 11. The areas represented in the various colors, as defined in the legend of Figure 5, make it difficult to propagate the sound wave, dissipating much of its energy, already in the vicinity of the transformers.

Presented below is Table 2, which illustrates vertical noise maps, generated from numerical simulation. The images were obtained by applying a cut in relation to a section of the transformers, indicated by a blue line next to Figure 6 . The transformers are installed near the substation command building. The vertical sections have been defined to facilitate the analysis, with a standard height of 20 meters.

Such a table has been set up to ensure the possibility of directly visually analyzing variations in sound pressure levels when the different settings, already detailed in Table 1, are tested. Besides these, configurations C2, C3 and C4 were simulated, without the use of top geometries. 
Figure 11 - 3D view of the $\mathrm{C} 5$ configuration.

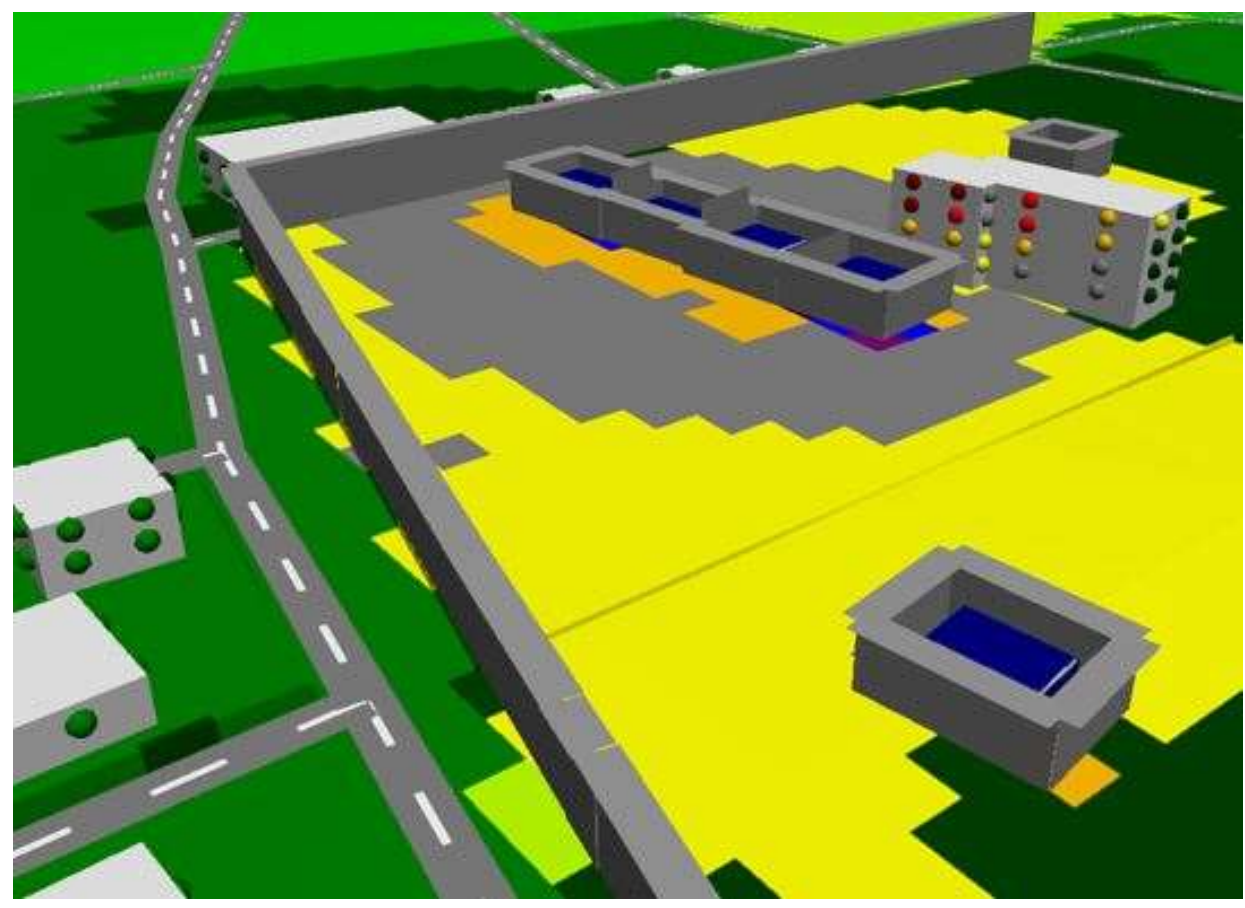

Source: Authors.

The calculation area used to generate the results of Table 2 was positioned on the central transformers, TR1 to TR4, extending it to one of the residences neighboring the substation, illustrated to the left of the figure (white block, bottom left corner). To facilitate the understanding of the vertical section, the observer should orient himself/herself by the wind rose present in the lower right corner of the figure, positioning him/herself on the left and viewing the substation in an easterly direction, according to Figure 6. This cutting section is applied to all the configurations, in order to guarantee a pattern for the area studied. Analyzing the dispersion of the vertical sound maps, it can be seen that the propagation takes place in a radial way, the configuration being called $\mathrm{C} 1 \mathrm{~A}$ relative to the simulation with the condition in which the substation is currently located, that is, standard condition.

The configurations described as C2, C3, C4 and C5 bring with them, in numerical simulation, a variant called top, in which a T-shaped flap is added next to the barrier. For variants $\mathrm{C} 2, \mathrm{C} 3$ and $\mathrm{C} 4$, one more possibility is incorporated into the analysis, not inserting flaps at the top of the barrier. When comparing the settings created with the standard model (C1A), noise attenuation is noticeable on both the left and right edges of all images contained in Table 2 . In some cases, there is alternation between the bordering and gray areas, which have sound ranges of 65 to $70 \mathrm{~dB}$ and 50 to $55 \mathrm{~dB}$ respectively.

Another important characteristic found is linked to top geometries, which tend to reduce the radius of the sound wave in the horizontal direction of propagation and increase the noise in the vertical direction. This characteristic becomes important in regions where there are buildings adjacent to the analyzed site.

The C4 and C5 configurations presented the best results in the simulation, as can be seen through their respective images. It is observed that the inclusion of barriers, enclosing the transformers and bypassing a good part of the substation perimeter, provides an attenuation that guarantees sound levels close to the residence that vary from 35 to $55 \mathrm{~dB}$, alternating between the green, yellow and gray areas, according to data in Figure 5. 
Table 2 - Vertical Noise Maps on Central Transformers.

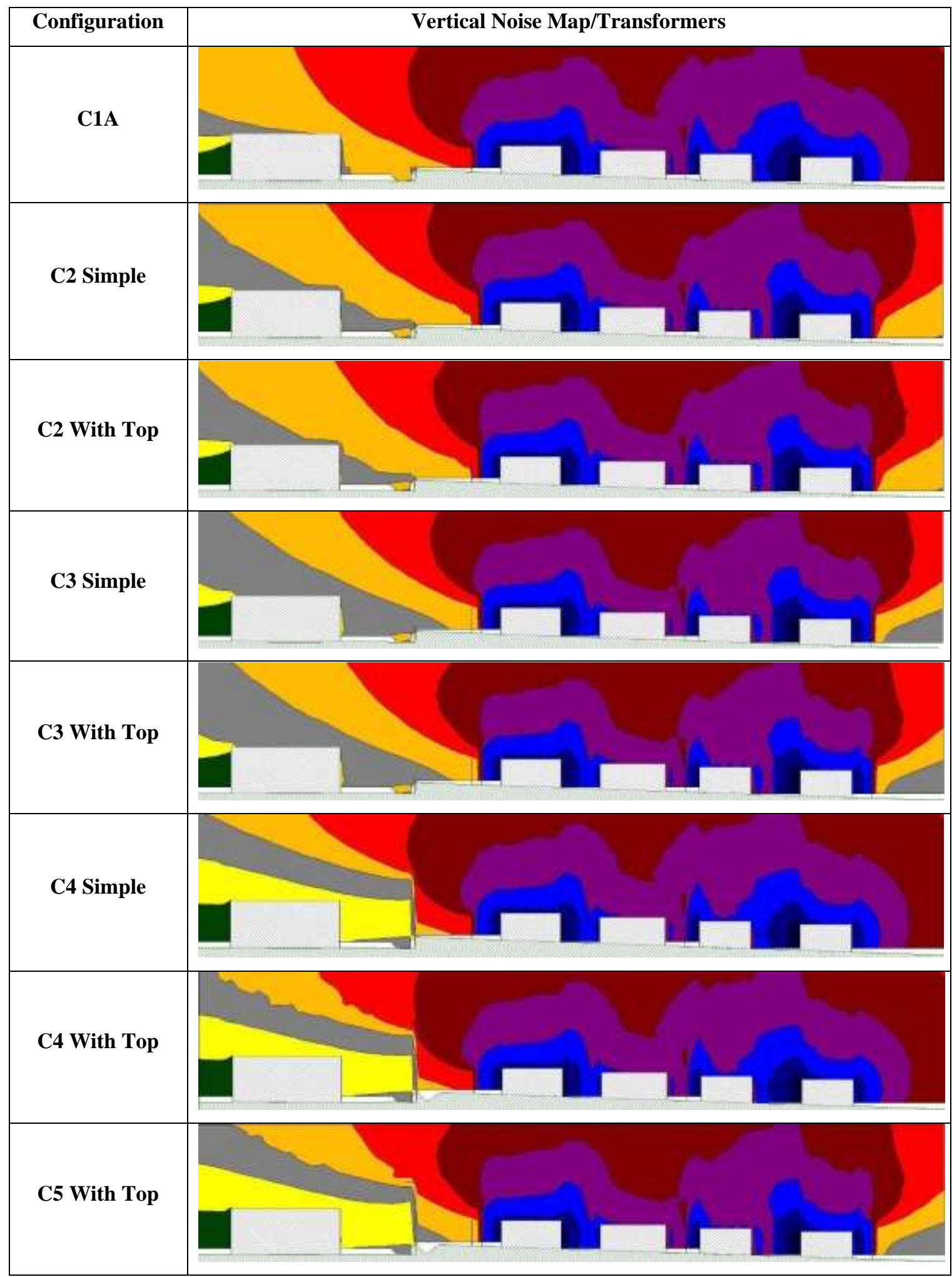

Source: Authors.

Table 3 summarizes the results of the vertical calculation areas that cross the TR 1 transformer and the command building (further right), as indicated by one of the blue lines in Figure 6. More to the left, of all the images linked to the table, one of the residences near the substation. To facilitate the understanding of this cut, the observer should be guided by the TR6 transformer, which is located further south of the substation, viewing it in a north direction, as shown in Figure 6. 
All the configurations indicated in Table 1 were simulated, adding to them the configurations $\mathrm{C} 2, \mathrm{C} 3$ and $\mathrm{C} 4$, without the use of top geometry. Visually, using the color maps, it is noticed, due to the radial dispersion of the colored areas, that the noise levels are lower for all variations, when compared to the current configuration, C1A.

When analyzing the $\mathrm{C} 2$ and $\mathrm{C} 3$ settings, with top and simple, a very small change in their respective color maps is noticed. The little influence of the top geometries, in these cases, is due to the low frequencies emitted by the transformers, which as explained in section 2.5, facilitates the diffraction of the sound wave, making noise mitigation difficult. Furthermore, it can be seen that the lower noise levels observed in the $\mathrm{C} 3$ configurations, if compared to those linked to $\mathrm{C} 2$, are the result of the encapsulation of the transformers.

The C4 and C5 configurations present lower noise levels, close to the residence, if compared to the other variations. This is due to the greater height of the barrier positioned at the substation perimeter, corroborating what was indicated in section 2.3. This situation occurs because the diffraction, due to the barrier being higher, makes the arrival of the sound wave to the receiver (residence) difficult.

Using the 'Insertion Loss' indicator, presented in section 2.3, which describes if the sound level was affected by the insertion of the barriers, it is also possible to evaluate the vertical noise maps indicated in Table 3 . Thus, it is assumed that the most significant results are linked to the $\mathrm{C} 4$ and $\mathrm{C} 5$ configurations, mixing the encapsulation of the transformers and the barrier installed at the substation perimeter with a height of $9 \mathrm{~m}$, even without observing significant changes due to the use of top geometries.

In Table 4 the main results obtained in the simulations are summarized and linked to their respective configurations. Criteria of greater relevance (CRAEB), related to each variation, are also highlighted. In addition, the maximum sound pressure level outside the substation perimeter, found in each of the simulations, and the values of the highest insertion loss (IL), generated by each configuration, when compared to the results relative to the current situation, C1A, are presented. It should be noted that the points where the greatest noise reductions occur are not coincident for all variations.

The alternatives $\mathrm{C} 3$ and $\mathrm{C} 4$ presented similar noise reductions, however, due to different reasons. In variant $\mathrm{C} 3$, the encapsulation of the transformers proved to be more effective for noise reduction, since it prevents diffraction through the sides of the barriers, while for $\mathrm{C} 4$, the acoustic shadow zone, generated by a barrier that has greater height, made such reduction possible.

Also, it can be identified that for the $\mathrm{C} 4$ and $\mathrm{C} 5$ configurations, the greatest differences between sound pressure levels are obtained, when they are compared to the current configuration, C1A. 
Table 3 - Vertical Noise Maps Over the Command Building.

\begin{tabular}{|c|c|c|c|}
\hline Configuration & \multicolumn{3}{|c|}{ Vertical Noise Map/Command Building } \\
\hline C1A & & & \\
\hline C2 Simple & & & \\
\hline C2 With Top & & & \\
\hline C3 Simple & & & \\
\hline C3 With Top & & & \\
\hline
\end{tabular}

Source: Authors. 
Table 4 - Overview of Results for Different Settings.

\begin{tabular}{|c|c|c|c|}
\hline \multicolumn{2}{|c|}{ Summary of Results- Horizontal Maps } \\
\hline Configuration & $\begin{array}{c}\text { Maximum Sound } \\
\text { Pressure Level (dB) }\end{array}$ & $\begin{array}{c}\text { Higher Insertion Loss } \\
(\mathbf{d B})\end{array}$ & CRAEB* \\
\hline C1A & 61 & - & - \\
\hline C2 & 59 & 4 & $\begin{array}{c}\text { Barriers installed next to } \\
\text { the transformers }\end{array}$ \\
\hline C3 & 53 & 12 & $\begin{array}{c}\text { Total encapsulation of } \\
\text { transformers }\end{array}$ \\
\hline C4 & 50 & 13 & $\begin{array}{c}\text { Higher barrier height } \\
\text { C5 }\end{array}$ \\
\hline & 48 & 17 & $\begin{array}{c}\text { Total enclosure of the } \\
\text { transformers allied to the } \\
\text { greater height of the } \\
\text { barrier }\end{array}$ \\
\hline
\end{tabular}

*CRAEB - most relevant criterion for increasing barrier efficiency. Source: Authors.

\section{Conclusion}

From simulations, detailed throughout the study, it is concluded that there is a possibility of obtaining real efficiency gains, mitigating the noise existing today, when different types of barriers are installed at strategic points of the substation.

It was highlighted configurations where the barriers were positioned in the perimeter of the substation, with a greater height than the others tested, besides those that use the idea of total enclosure of the transformers.

The use, in some variants, of top geometries did not generate the results previously glimpsed, due to the characteristics of the noise emitted by the sound sources present in the substation. Another conclusion regarding such geometries is associated with their dimensions, which generate an increase in efficiency as the top width approaches the height of the barrier. In this research such a possibility would be made impossible due to the interference between the top of the barrier and the transformer wiring.

In cases where less noise reductions are required, it is advisable to use the four side barriers to the transformers, linked to the $\mathrm{C} 2$ configuration. This is because, besides the smaller amount of material to be used in their construction, there will be less influence on heat exchanges, avoiding the heating of the transformer.

In the situation where the transformers are enclosed, C3, the reduction was more accentuated, mitigating on average 9 $\mathrm{dB}$, and may reach $12 \mathrm{~dB}$ in some homes near the substation. Such configuration can be used in situations where a great sound reduction is necessary, however in some cases it will be necessary to rethink the form of cooling of the transformers, in view of their loss of efficiency due to heating.

Looking for a solution that corrects all the inconveniences highlighted above, the configuration with higher barriers, $\mathrm{C} 4$, positioned on the perimeter of the substation is indicated, thus reducing the sound level in nearby residences without affecting the heat changes of the transformers. This configuration generated similar results to those associated with the enclosure of the transformers, with an average reduction of $9 \mathrm{~dB}$, which can reach $13 \mathrm{~dB}$ in some points. In this case the obstacle would be the large amount of material needed to build the barrier, which could also infringe some municipal regulations.

The last simulated configuration combined the enclosure of the transformers and barriers installed in the perimeter of the substation, generating a large reduction in sound level, around $14 \mathrm{~dB}$ with values reaching $17 \mathrm{~dB}$ in some homes. 
Finally, it is observed that the use of acoustic barriers can be a viable solution for several situations, whether occasional or not. However, a previous analysis is needed, not only related to the issue of noise reduction, but also related to costs, compliance with current regulations, operational safety, among others.

It is still indicated for future studies to evaluate the case with greater specificity, for the implantation of barriers with the best cost benefit, also verifying the possibility of using barriers of different materials and acoustic properties.

\section{Acknowledgements}

The authors thank the financial support of the Companhia Estadual de Energia Elétrica - Geração e Transmição (CEEE-GT) and especially to the manager, Daniel Wagner de Castro Lima, through the Research and Development Program of the National Electric Power Agency (ANEEL) under contract no. 5000003835, as well as the institutional support of the Fundação Universidade de Passo Fundo (FUPF). They also thank the colleagues of LINTEC, Juliano Wagner Daronch and Pamela de Matos, for their assistance with the article.

\section{References}

ABNT NBR 10151, de 31 de março de 2020. Acústica - Medição e avaliação de níveis de pressão sonora em áreas habitadas - Aplicação de uso geral. Rio de Janeiro: Associação Brasileira de Normas Técnicas.

Assunção, A. A., Abreu, M. N. S., \& Souza, P. S. N. (2019). Prevalência de exposição a ruído ocupacional em trabalhadores brasileiros: resultados da Pesquisa Nacional de Saúde. Cad. Saúde Pública, 35(10).

Attenborough, K. (2002). Sound Propagations close to the ground. Annual Review of Fluid Mechanics, 34, 51-82. 10.1146/34.081701.143541

Bies, D. A., \& Hansen, C. H. (2003), Engineering Noise Control: Theory and Practice. Spon Press.

Daigle, G. (1999). Final Report: Technical assessment of the effectiveness of noise walls. I-INCE Publication, 99-1, 137-161. http://i-ince.org/

de Castro, A. C. L., Fontes, K. D. de S. A., Ferreira, T. E. D., \& Gontijo, H. M. (2019). Addressing the impact of environmental noise in public schools in the city of Minas Gerais. Research, Society and Development, 8(3), e1683716. 10.33448/rsd-v8i3.716

Fachin, O (2005). Fundamentos de Metodologia. Editora Saraiva.

Federal Highway Administration. (2014). Environment. https://www.fhwa.dot.gov/environment/noise/

Freitas, E., \& Trabulo, L. (2007). Desempenho de Barreiras Acústicas: Dois métodos de avaliação. Revista Engenharia Civil. 29, 15-26. http://repositorium.sdum.uminho.pt/

Hendriks R., Rymer B., Buehler D., \& Andrews J. (2013). Technical Noise Supplement to the Caltrans Traffic Noise Analysis Protocol: A Guide for the Measuring, Modeling, and Abating Highway Operation and Construction Noise Impacts. Departamento de transportes de California.

Langaro, D. D., \& Setti, A. (in press). Padronização de Medições de Níveis de Pressão Sonora e Estudo de Caso Sobre Ruídos Acústicos em Subestação de Energia Elétrica. Passo Fundo, 2020.

Larsson, C. (1997). Atmospheric absorption conditions for horizontal sound propagation. Applied Acoustics, 50(3), 231-245. 10.1016/S0003-682X(96)00068-0

Leissing, T. (2007). Nonlinear outdoor sound propagation. (Dissertação de mestrado). Departamento de Engenharia Civil e Ambiente da Universidade tecnológica de Chalmers,

Lei $\mathrm{N}^{\mathrm{o}}$ 4763, de 18 de janeiro de 2011. Dispõe sobre os valores máximos de ruído e dá outras providências. https://leismunicipais.com.br/a/rs/p/passofundo/lei-ordinaria/2011/476/4763/lei-ordinaria-n-4763-2011-modifica-a-redacao-da-lei-n-2427-de-27-de-abril-de-1988-e-da-outras-providencias

Resolução $\mathrm{N}^{\circ}$. 02/2015. Regulamenta o volume e a frequência dos sons produzidos por fontes fixas e dá outras providências. http://www.pmpf.rs.gov.br/servicos/geral/multimidia/propostaDeResolucaoCMMA.pdf

Radoi, A. (2015). The Establishing of the Insertion Loss of the Noise Barriers. DAAAM International Scientific Book (pp.173-188). B. Katalinic

Tadeu A., António, J., \& Castro, I. (2012). Sound pressure attenuation provided by a 3D rigid acoustic barrier on a building façade: the influence of its longitudinal shape. Boundary Elements and Other Mesh Reduction Methods XXXIV, 53, 25-27. 10.2495/BE120221

Wakefield Acoustics Ltd., (2012). City of Vancouver Noise Control Manual.

Watts, G. (2002). Barrier designs to reduce road traffic noise. Proceedings of the Institution of Civil Engineers. 153(2), 79-86. 10.1680/tran.2002.153.2.79 
Research, Society and Development, v. 10, n. 6, e8710615339, 2021

(CC BY 4.0) | ISSN 2525-3409 | DOI: http://dx.doi.org/10.33448/rsd-v10i6.15339

WHO - World Health Organization. (2011). Burden disease from environmental noise qualification of healthy life years lost in Europe. Quantifying environmental health impacts. https://www.who.int/quantifying_ehimpacts/publications/e94888/en/\#: :text=Environmental\%20burden\%20of\%20diseas e 20 from $\% 20$ noise $\% 20$ in $\% 20$ Europe $\% 20 \% 2 \mathrm{D} \% 20$ WHO\%20EURO\&text=The\%20health\%20impacts\%20of\%20environmental,the\%20western\%20part\%20 of\%20Europe 